\title{
Teaching Effectiveness and Bibliographic Instruction: The Relevance of Learning Styles
}

\section{Sonia Bodi}

Bibliographic instruction librarians frequently wonder how they can improve the effectiveness of their teaching. While several factors identify effective teaching, it can be argued that the most important component is teaching to the learning styles of the students. Therefore, this paper will examine learning styles in general and David A. Kolb's theory of experiential learning in particular. The paper will also show how Kolb's theory is used in the freshman library instruction program at North Park College.

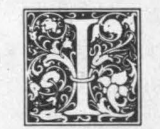

$\mathrm{n}$ recent years it has become commonplace to find articles in the professional literature addressing all aspects of bibliographic instruction. Some of these articles report successful ventures in changing the views of skeptical administrators, in persuading apprehensive professors to participate in bibliographic instruction, and in changing students' attitudes of intimidation and reluctance about the library to those of confidence and encouragement. Other articles report on the entire range of successful and not-so-successful bibliographic instruction programs for students, including $\mathrm{K}-12$, undergraduate, graduate, minority, and foreign students. Librarians have access to a wealth of information adaptable to their own libraries, information about political strategies to develop or enhance programs, and information about the content and methodology of bibliographic instruction. Many of us have successfully overcome the institutional hurdles; have one or perhaps many bibliographic instruction programs in place; and have excellent content, appropriate strategies, and useful tools to aid the students. Nevertheless, some students dislike the instruction, see no relevance, and are bored. Sometimes we are not too excited about it either.

What is the missing component? Is it enthusiasm and a pleasant voice? Certainly the library community needs to know more about what makes a librarian an effective teacher of bibliographic methodology. We need to know how to be as effective as possible during the fifty- to seventy-minute session most of us have with students.

This paper will examine briefly the research into effective teaching and will then focus on learning styles and how the understanding of styles is relevant to effective teaching. Finally, the paper will describe how the use of David Kolb's experiential learning style has improved the freshman library instruction program at North Park College.

Sonia Bodi is Head Reference Librarian and Associate Professor at North Park College and Theological Seminary, 3225 W. Foster Ave., Chicago, Illinois, 60625. 


\section{TEACHING EFFECTIVENESS}

A simple and precise definition of teaching effectiveness is "the degree to which one has facilitated student achievement of educational goals."' Assessing teaching effectiveness is not simple because student achievement is affected by many factors outside the teacher's control; e.g., student ability, motivational level, and prior experience. However, student learning is the ultimate criterion of teaching effectiveness. Some research indicates that students rate higher those professors from whom they learn the most. ${ }^{2}$ If this is true, the focus of attention should be more on how to help students learn than on how the librarian should perform, although arguably one cannot be separated from the other.

Numerous studies have explored the dynamics of effective teaching. Yet identifying teacher effectiveness and distinguishing between more and less effective teachers remain major research problems. ${ }^{3}$ Furthermore, many of the findings contradict one another. There is an elusive quality to assessing teaching effectiveness that makes it more complex and expensive to do well than research in most other areas of education. The findings are also difficult to understand. Although the qualities cited may be somewhat different in each study, there are some qualities of effective teaching that are found in nearly all studies. In his seminal work, The Art of Teaching, Gilbert Highet identifies three essentials of good teaching. First, the teacher must know the subject. ${ }^{4}$ For librarians this means knowing many subjects well enough to know the most appropriate and most significant sources to use in each and to present them in a manner relevant to the subject. Teachers must also continue to be learners of new theories, new methods, new sources; teaching and learning are inseparable. The second essential quality is to enjoy what we do. This quality is connected with the first; we cannot continue learning without being interested in the subject. If we enjoy the subject, we will be able to teach even if we are tired; we will never be at a loss for a new illustration or an interesting point of view. Finally, teachers must like and under- stand their students. ${ }^{5}$

Interestingly, there is little evidence to support the popular view that students value entertainment over substance in teaching. While effective teachers may also be entertaining, they are not necessarily so. Instead, clarity of the teacher's presentation is highly valued. This quality includes the use of examples, illustrations, and summaries, as well as the ability to communicate clearly abstract ideas and theories. A second quality is preparation and organization. Students appreciate teachers who stress the important material and who have a beginning, middle, and end to their lectures. Thirdly, students value teachers who inspire confidence in their knowledge of the subject. Finally, enthusiasm for teaching and a lively and energetic interest in the subject are important for effective teaching. Another related quality is concern and respect for students and availability to help. ${ }^{6}$

Very likely none of these qualities comes as a surprise. We do know, however, that when students evaluate bibliographic instruction, they often disagree sharply in their appraisal of the librarian's presentation. If student learning is the ultimate criterion of effective teaching, then we need to examine what the students perceive they have learned. George Domino writes that the interaction between learning style and teaching style affects both the amount of learning and the satisfaction with teaching. Students who are taught in a manner incompatible with the way they learn learn less and express less satisfaction with the effectiveness of the teacher. ${ }^{7}$

\section{LEARNING STYLES}

Learning styles is a broad term that includes the cognitive, affective, and physiological. Our cognitive style is how we perceive and process information. Our affective style is how we feel about and value learning experiences. Our physiological style involves the environment for effective learning, as well as the time of day we learn best, the lighting and noise level we require, and the position our bodies need to be in to facilitate learning. The characteristics of style reflect genetic coding, personality development, motiva- 
tion, and environmental adaptation.

Learning style tends to be stable throughout life, but it can change as circumstances demand. Sometimes students must adapt their learning styles in order to succeed because they will not always have the ideal learning environment. ${ }^{8}$ Learning style does not include ability or intelligence and no one style of learning is superior to another style. There are many theories of learning styles. ${ }^{9}$ Each has its strengths and shortcomings.

\section{"Knowledge of learning styles is ap- propriate for all levels and kinds of bibliographic instruction."}

It is important to note that teaching is not a mere dual relationship between teacher and student, but a triadic relationship of teacher, students, and subject matter. Learning style paradigms generally omit consideration of subject matter, but it is essential to relate a learning style theory to the praxis of the subject. ${ }^{10}$ In other words, the theory chosen is not as important as choosing a theory and structuring bibliographic instruction around it. Furthermore, knowledge of learning styles is appropriate for all levels and kinds of bibliographic instruction.

Students enter learning situations with established learning styles. Most teaching methods, however, appeal only to a certain learning style and handicap those who would prefer to learn in another way. Kolb suggests a shift from teacher as dispenser of information to coach or manager of the learning process. ${ }^{11}$ Knowledge of students' learning styles can equip us with important skills in teaching, but we can also benefit from a knowledge of our own learning styles. We frequently teach in the same manner we have been taught, but our teaching styles may not match our own learning styles. ${ }^{12}$ If there is a mismatch, students may view a teacher negatively. H. A. Witkin argues that teachers may do better with students similar to themselves in cognitive style and students may learn more effectively when taught by teachers matched to them in style. ${ }^{13}$

The results of a 1982 study at Purdue University involving 600 economics students and 20 economics faculty suggest two major conclusions about the divergence between learning and teaching styles. First, the larger the divergence between styles, the lower the students' gain in achievement; and the greater the divergence between styles, the less positive the students' attitude toward the subject. ${ }^{14}$ However, awareness of learning style does not guarantee effectiveness or excellence in teaching if combined with a weak grasp of the subject.

\section{DAVID KOLB'S THEORY OF EXPERIENTIAL LEARNING}

David Kolb is an organizational psychologist at Case Western Reserve. His theories are specifically used in management, but they have significant implications for education. The theory of experiential learning is that ideas are not fixed but are formed and reformed through experience. ${ }^{15}$ The emphasis is on process rather than on outcomes. It stresses the role of process in life-long learning, an important goal in bibliographic instruction. Experiential learning is a holistic, integrative perspective on learning that combines experience, perception, cognition, and behavior. ${ }^{16}$

The substance of Kolb's theory is illustrated by the circle in figure 1 . While the circle is a practical illustration it is also a metaphor for the never-ending cycle of new learning. Our job as educators is not only to introduce new ideas but to dispose of or modify old ones. Learning by its very nature is a tension and conflict-filled process as new knowledge, skills, or attitudes are assimilated. The learning process is facilitated by bringing out the students' beliefs and theories, examining and testing them, and integrating new, more refined ideas into their belief systems. Kolb defines learning as the process whereby knowledge is created through the transformation of experience. ${ }^{17}$ To be effective learners, students need to engage in the four kinds of activities identified in the circle. As librarians our instruction must be 


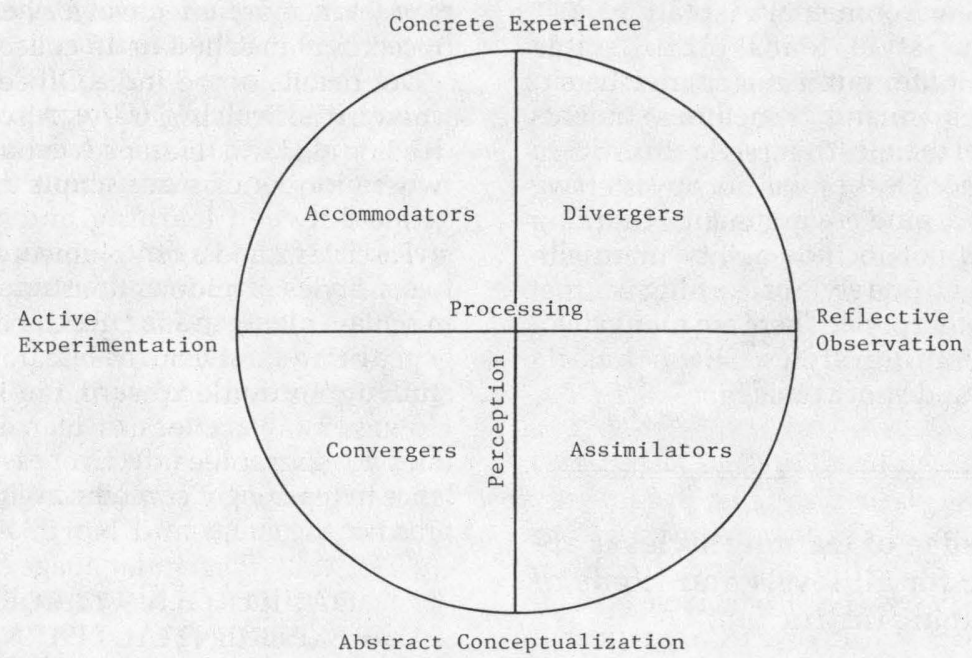

FIGURE 1

structured to include these activities.

At the top of the circle is concrete experience. ${ }^{18}$ Students must be able to involve themselves fully, openly, and without bias in new and immediate experiences. Immediate personal experience is the focal point for learning, giving personal meaning to abstract concepts and at the same time providing a concrete reference point for testing the validity of ideas. In reflective observation students must be able to reflect on and observe their new experiences from different perspectives and to think about and interpret new data. From these reflective observations, students create concepts that integrate their observations into sound theories: abstract conceptualization. Abstract conceptualization also involves analysis and synthesis. Finally, in active experimentation students must be able to use these theories to make decisions and to solve problems that result in another concrete experience. At this stage the circle of learning begins again.

Kolb identifies perception and processing as two major dimensions of learning. Concrete experience and abstract conceptualization are two opposite kinds of perception. We are all stronger at one than the other. Furthermore, active experimentation and reflective observation are two opposite kinds of information processing. Again we are stronger at one of these than the other. We move in varying degrees from actor to observer and from specific involvement to general analytic detachment. We learn in different ways depending on our strengths. Those who learn best through a combination of concrete experience and reflective observation are called divergers. These learners look at alternative ideas and in reaching a decision they seek background information, investigate new patterns, and recognize discrepancies and problems. One thought, idea, or fact stimulates other ideas. Learners who combine abstract conceptualization and reflective observation in their learning styles are assimilators. Their strengths lie in planning and formulating theories but sometimes they have difficulty giving practical application to their ideas. These learners excel at inductive reasoning and can assimilate disparate ideas into an integrated explanation. Convergers are those who learn best through active experimentation and abstract conceptualization. They learn through analysis and are swift to make decisions. Convergers are always looking for connections, ways to tie things together. While divergers enjoy group discussion 
and brainstorming, convergers learn best through lectures. Finally, accommodators learn through active experimentation and concrete experience. They are accomplishment and goal-oriented, but they need frequent feedback on their work to keep them focused on the task at hand. They are strong at advocating positions or ideas, at setting objectives, and at implementing decisions, and they tend to solve problems through intuition rather than by analysis.

Kolb calls divergers and accommodators "lumpers," or those who need to see the whole picture before they can learn the details and facts related to the concept. $\mathrm{He}$ calls assimilators and convergers, "splitters," or those who need to analyze the parts before they can learn the whole concept. ${ }^{19}$ We all fall, more or less, into one category or the other. It should be cautioned, however, that all styles of learning are complex and are not easily described in simple terms.

While we all have a preferred style of learning, those who learn best are those who are able to adapt their learning styles as situations demand a change. By using Kolb's theory in our instruction, we will help students to learn in their own styles and to develop abilities in all four quadrants of the circle, thus increasing their effectiveness as learners.

\section{BIBLIOGRAPHIC INSTRUCTION USING KOLB'S THEORY OF EXPERIENTIAL LEARNING}

During the past three years we have used Kolb's theory of experiential learning as the learning style structure for the freshman library instruction program at North Park College. North Park is a private liberal arts college located in Chicago with about 900 full-time-equivalent students. It also has a seminary with an enrollment of about 150 and extension programs in two Chicago neighborhoods. Two fine instructional librarians work individually with our students, particularly in freshman library instruction. All freshmen receive library instruction in their English Composition 101 classes. A search strategy approach emphasizes the use of subject encyclopedias, bibliographies, book reviewing sources, and sources for information about authors.

Until three years ago, about thirty percent of the freshmen thought the instruction was a waste of time. Some wrote strong, dreadful comments on their evaluation forms. We could not understand this negative reaction when everything about the instruction seemed to be good. We looked carefully at the style of teaching and at the content of the instruction but found no answers. It occurred to us that perhaps the answer was in the style of learning rather than in the style of teaching. After studying Kolb's theory it became clear that we were not addressing reflective observation.

Our instruction now uses all four activities in Kolb's theory. We teach to all four styles of learning. This has led to striking results. The concrete experience is the lecture. We give each student a worksheet and a booklet that explains it in detail. Students follow the lecture with the booklet and worksheet in hand. Examples of the books and journals used in the lecture are passed around so each student has an opportunity to handle and look through the sources. There are several opportunities for discussion and questions. This is a lot to accomplish in fifty to seventy minutes, but we do provide students with a reasonably well-rounded concrete experience. We are teaching to convergers with the lecture and to divergers with the discussion. The assignment is to complete the worksheet and write a partially annotated bibliography on a controversial issue of their choice. This assignment is followed by a five-page research paper on the same topic using the resources in the annotated bibliography. The English Composition instructors supervise the writing of the research paper.

The activity we were not including prior to using Kolb's theory was reflective observation. Including reflective observation accounts for the significant improvement in students' perception of the value of instruction. Halfway through the assignment we meet with students individually. During this conference students ask questions and we provide feedback on their progress. Providing feedback is im- 
portant for the accommodator's learning style. We also ask students to compare what they knew about using a library before doing the assignment now, and after in order to answer the question, What have you learned? This gives students an opportunity to reflect on what they have been learning. They are usually surprised with their newly gained knowledge. We ask the same question on the postinstruction evaluation form. Since including time for reflective observation we rarely encounter hostile written comments.

\section{"Providing feedback is important for the accommodator's learning style."}

Students engage in abstract conceptualization as they develop their search strategies. They must think about their topics and choose the most appropriate resources. Assimilators learn best at this stage as they plan and formulate strategies.

The actual doing of the assignment involves active experimentation. Accommo- dators, who are goal-oriented, meet their needs at this stage. Moreover, active experimentation is essential in building the foundation for handling a new concrete experience but at a more advanced level of bibliographic instruction.

Our program of teaching to the four styles of learning has resulted in an 80 to 90 percent favorable response rate for freshman library instruction instead of a 70 percent favorable rate in prior years. Table 1 shows the response to several of the questions asked on the evaluation form during the 1988-89 academic year. It is almost identical to the responses of the previous two years.

\section{CONCLUSION}

Bibliographic instruction is a multifaceted process involving a complex relationship between librarian, content, and student. Efforts to improve instruction should balance the attention given to each. In trying to understand this very elusive quality called effective teaching, we discovered that meeting the various learning modes of students may be the key to improving teaching effectiveness. ${ }^{20}$

Kolb's theory of experiential learning offers a comprehensive design for structur-

\section{TABLE 1}

\section{STUDENT EVALUATIONS OF FRESHMAN LIBRARY INSTRUCTION $(\mathrm{N}=119)$}

1. Do you think that learning the basic search strategy (the process of finding information in a logical manner) will be helpful to you in the future when you are required to write a research paper?

$\begin{array}{ll}\text { Yes } & 91 \% \\ \text { No } & 9 \%\end{array}$

2. How confident do you feel in your ability to use the library compared to your level of confidence before you took the instruction?

Felt confident before taking the instruction 23\%

Much more confident

Somewhat more confident $\quad 50 \%$

Still don't feel confident $\quad 5 \%$

Completely confused $3 \%$

3. As you think over what you've learned about using the library, how useful do you think this instruction was for your research paper?

$\begin{array}{lr}\text { Very useful } & 26 \% \\ \text { Somewhat useful } & 55 \% \\ \text { Not very useful } & 16 \% \\ \text { Useless } & 3 \%\end{array}$

4. As you think over what you've learned about using the library, how useful do you think this instruction will be for your future research and information needs?

$\begin{array}{lr}\text { Very useful } & 39 \% \\ \text { Somewhat useful } & 50 \% \\ \text { Not very useful } & 10 \% \\ \text { Useless } & 1 \%\end{array}$


ing learning experiences. Students are provided opportunities in a mode that is personally most effective. They also strengthen their learning skills in other areas. Kolb's theory is significant but there are others yet to be studied and tried in our instructional programs.

Will addressing learning styles directly make our instructional programs perfect? Probably not. But teaching to a diversity of learning styles will probably help us to be more effective instructional librarians.

\section{REFERENCES AND NOTES}

1. This definition is expressed in nearly identical words in Wilbert J. McKeachie, "Student Ratings of Faculty: A Reprise," Academe 57:384-97 (Oct. 1971); Peter A. Cohen, "Student Ratings of Instruction and Student Achievement: A Meta-analysis of Multisection Validity Studies," Review of Educational Research 51:281-309 (Fall 1981); N. L. Gage, The Scientific Basis of the Art of Teaching (New York: Teachers College Press, 1978), p.14; Donald M. Medley, "Teacher Effectiveness, " in Encyclopedia of Educational Research, 5th ed. (New York: The Free Press, 1982), p.1894.

2. Cohen, "Student Ratings," p.301; McKeachie, "Student Ratings," p.384.

3. Medley, "Teacher Effectiveness," p.1894.

4. I will be using the words "teacher" and "librarian" interchangeably.

5. Gilbert Highet, The Art of Teaching (New York: Vintage Books, 1950), p.12-26.

6. Kenneth A. Feldman, "The Superior College Teacher from the Students' View," Research in Higher Education 5:243-48 (1976); John A. Centra, "How to Develop a Teacher-Rating Instrument: A Research Approach," Journal of Higher Education 46:653-63 (Nov./Dec. 1975); McKeachie, "Student Ratings," p.395; Frank Costin, "Student Ratings of College Teaching: Reliability, Validity and Usefulness," Review of Educational Research 41:511-35 (Dec. 1971); Cohen, "Student Ratings," p.283.

7. George Domino, "Interactive Effects of Achievement Orientation and Teaching Styles on Academic Achievement," Journal of Educational Psychology 62:427-31 (Oct. 1971).

8. James W. Keefe, ed., Profiling and Utilizing Learning Style (Reston, Va.: NASSP, 1988), p.2-37.

9. Several of the major current learning style theories are described in the following sources: $\mathrm{H}$. A. Witkin, "Field-Dependent and Field-Independent Cognitive Styles and Their Educational Implications," Review of Educational Research 47:1-64 (Winter 1977); Mary Jane Even, "Adapting Cognitive Style Theory in Practice," Lifelong Learning: The Adult Years 5:14-27 (Jan. 1982); Keefe, Profiling and Utilizing Learning Style; Pat Burke Guild and Stephen Garger, Marching to Different Drummers (Alexandria, Va.: ASCD, 1985); Ronald Hyman and Barbara Rostoff, "Matching Learning and Teaching Styles: The Jug and What's In It," Theory Into Practice 23:35-43 (Winter 1984); James W. Keefe, Learning Style Theory and Practice (Reston, Va.: NASSP, 1987); Rita Dunn, "Learning Style Researchers Define Differences Differently," Educational Leadership 38:372-75 (Feb. 1981); and Charles S. Claxton and Patricia H. Murrell, Learning Styles: Implications for Improving Educational Practices (Betheseda, Md.: ERIC Document Reproduction Service, ED 293 476, 1987).

10. Hyman and Rosoff, "Matching Learning and Teaching Styles," p.35-38.

11. David A. Kolb, Experiential Learning: Experience as the Source of Learning and Development (Englewood Cliffs, N.J.: Prentice-Hall, 1984), p.202.

12. Keefe, Profiling and Utilizing Learning Style, p.38.

13. Witkin, "Field-Dependent and Field-Independent," p.32-36.

14. R. J. Charkins, "Linking Teacher and Student Learning Styles with Student Achievement and Attitudes," Journal of Economic Education 17:111-20 (Spring 1985).

15. Kolb, Experiential Learning, p.26.

16. Ibid., p.20-25.

17. Ibid., p.28-30, 41.

18. Kolb's experiential learning theory is described in Kolb, Experiential Learning; Barbara Carlsson, "R\&D Organizations as Learning Systems," in David A. Kolb, Organizational Psychology: A Book of Readings, 3d ed. (Englewood Cliffs, N.J.: Prentice-Hall, 1979), p.36-46; Claxton, Learning Styles; and Guild, Marching to Different Drummers.

19. Claxton, Learning Styles, p.41.

20. For a study applying Kolb's theory to the learning styles of librarians, see Jin M. Choi, "Learning Styles of Academic Librarians," in College \& Research Libraries 50: 691-99 (Nov. 1989). 